\title{
The Attitudes of Internal Auditors to Internal Audit Practice in Post-communist Countries - Case of Albania
}

\author{
Mustafa Üç ${ }^{1} \&$ Dritan Shehu ${ }^{1}$ \\ ${ }^{1}$ Department of Business Administration, Epoka University, Tirana/Albania \\ Correspondence: Mustafa Üç, Department of Business Administration, Epoka University, 1032, Tirana/Albania
}

Received: April 12, 2017

Accepted: July 27, 2017

Online Published: August 1, 2017

doi:10.5430/afr.v6n3p88

URL: https://doi.org/10.5430/afr.v6n3p88

\begin{abstract}
This paper aims to reveal the attitudes of internal auditors, towards overall internal audit practices in the post-communist country of Albania. The study presents the current state of internal audit practices in Albania from eyes of the internal auditors themselves. The study will explore the independence of the internal auditors, the level of professionalism they exhibit, the use of international standards, and whether current regulations are resulting in higher quality work in the profession. In order to study these objectives, a 169-person questionnaire was conducted, all participants where internal auditors from public and private sectors in Albania. The research findings of the study reveal that internal auditors can be assessed as independent in Albania, and that the private sector is the most independent. Regarding professionalism, internal auditors are able to detect and prevent fraud in companies. In this paper, we examine the international standards of auditing that are used by Albanian auditors; the international standards are really useful for internal auditors in Albania, even though there is much room for improvement. The number of participants was limited of 169 and analyzed one country. For the future researches questionnaire can be conducted more than one country to have comparative analysis. One improvement needed is the adaptation of the international standards in national regulations. This will make the international standards easier to apply and understand the standards in Albania.
\end{abstract}

Keywords: Internal Audit, post-communism, Albania

\section{Introduction}

Albania as a former socialist country and it has a very unique socialist history. In communist Albania there was a strict prohibition on private enterprise, and the prohibition of foreign loans through a constitutional ban. It must be also keeping in mind that many socialist countries in the same territory: Bulgaria, Romania, and Yugoslavia owed huge amounts of foreign debt at the same time Albania had outlawed it. In addition to this Yugoslavia, was one of the two land neighbours of Albania, the other one being Greece, and the agriculture in Yugoslavia predominantly in private sector (Jefriies, 1993). After Albania shifted the regime to socialism in 1945, Yugoslavia allied with Albania. But political tension between Yugoslavia and Soviet Union in 1948 changed Albania's foreign policy in favour of Soviet Union under the leadership of Stalin. After Stalin's death and a retreat from the Stalinist's policies in Soviet Union by the new administration causing tension between the Soviet Union and China, Albania's leader Enver Hoxha shifted his allegiance to China in 1961. Chinese influence through aid and technical support to Albania continued to 1976. The death of Mao however, ended the relationship between the two communist countries. Albania broke ties with China and adopted a policy of international isolation (Bideleux and Jeffries, 2007). Therefore Albania was the sole former socialist country that was loyal to the Stalinist model until the collapse of the regime in 1991 (Lavigne, 1999).

After the collapse of the communist regime in Albania in 1991, many reforms were made in the business sector, including in the auditing field. The enactment of the commercial code in 1992 was a breakthrough for auditing in Albania. This law recognized the importance of auditing in the business sector. More recently, in 2008, a new law was enacted, recognizing statutory auditing. This law also formed an organization to manage the processes' to increase qualified auditors. An increasing number of multinational companies started operating in Albania and they established internal auditing departments and employed internal auditors. Therefore internal auditing starts to function not only in public institutions but also in the private sector corporations. This study aims to reveal the attitudes of internal auditors toward overall internal audit practices in the post-communist country of Albania. The study will present the current state of the internal audit practice in Albania, from the eyes of Albanian internal 
auditors and it will explore; the independence and objectivity of internal auditors, their level of professionalism, the use of international standards on internal auditing, and the inherited traditions, working culture internal auditors poses. In order to fulfill these objectives a questionnaire was conducted for internal auditors in Albania.

In the next chapter we will review on the development of internal auditing in Albania in the following dimensions; internal audit profession, adaptation and use of international audit standards. The following chapter will discuss the methodology and findings of the research. An overall review of the study will be presented in the conclusion.

\section{A Historical Review on the Development of Auditing in Albania}

The Internal audit profession in Albania started in the 1990's after the communist regime was brought down by a student revolution and Albania was declared a Democratic Republic. The fragile economy of Albania was lacking experience in capitalistic economic regulations but still attempting to reach the standards and to be a European Union (EU) member, ready to participate and compete with other economies. Reforms on economic structure started to be undertaken by the government. "On Commercial Companies" law nr.7638 dated on 19.11.1992 was the first reform to establish the audit profession in Albania. This law set provisions for the statutory audit of the entities by professional auditors called "ekspert kontabel auditor authorized chartered auditors".

But there was still a need to figure out how to implement and deal with new regulations when accountants and auditors had no experience, no knowledge about the new law and profession, no training and little time, as these reforms had to be adapted very quickly. These were the challenges that Albania was going through in order to catch up and implement a model of high standard accounting, in a very short time (Cela, 2004).

In addition to the new commercial law, the first two regulations were approved in 1995. The regulations assisted the development of the profession of auditing by creating a self - regulating body, known as the "Institute of Authorized Chartered Auditors" Instituti I Eksperteve Kontabel te Autorizuar ne Shqiperi (IEKA). IEKA's objective is to improve the profession, standards, and quality of auditing in Albania. In 2008, a new law was approved by Albanian Parliament, law nr. 9901 named "On Commercial Companies". In this new law there were regulations and improvements of the previous laws and it was in accordance with the Eight Directive of European Union Parliament.

The law "On Statutory Auditing and Organization of Registered Chartered Auditors and Approved Accountants" was designed and approved in 2009. This law is the first legal act approved in Albania to regulate the organization and activity of registered chartered auditors and auditing companies. In drafting this law the $8^{\text {th }}$ Directive of the European Union Parliament, IFRS, and ISA were taken into consideration without leaving out the Code of Ethics published by the International Federation of Accountants (Shkurti et al., 2011).

Bello (2012) presents research into the role of internal auditing and development of this profession in the public sector in Albania. The research was focused on the actual situation of the internal auditing role in Albania, and evaluated the program of the professional development of auditors. Different recommendations were given according to concrete acts that could help the ongoing development of this profession by using the best international practices of internal auditing. The focus of their recommendations was the implementation of a new way of auditing, where besides internal auditing; there could also be contracted external part time professionals who could evaluate not only the financial department practices, but also evaluation of performance, human resources department, IT etc.

\subsection{Challenges of Auditing Profession in Albania}

In the 2000s, there were new challenges with the globalization of the accounting profession and the aspirations of Albania, which wanted to be a member of the EU. During this decade a lot occurred, but the most important event for this profession was the approved law "On organization of the Chartered Auditors and the Certified Accountants" in March 2009, based on the Law nr 10091, where professionals in Albania had to decide whether to be licensed as an auditor or accountant. This law separated these functions, in order to avoid the risk of conflict of interests by guaranteeing the efficiency and effectiveness of their work. Criteria were put in place in order to become a Certified Accountant in Albania. According to the law, the requirements were:

1. Having work experience in accounting, finance or other similar areas for at least three years,

2. Graduating with a major in economics such as finance, accounting and business administration,

3. Attending a qualification session in accounting and finance reporting (these qualification sessions are organized and administered by the respective accounting associations in Albania)

4. One had to pass two exams of professional proficiency, one in fiscal legislation in Albania, and the other one in accounting, financial reporting and analysis of financial statements. In the new law there was a major change to the criteria and the number of exams needed. The authority to make the testing procedures was given to The 
Certification Authority, whereas in the first law this duty was under the authority of the Accounting Directory in the Ministry of Finance in Albania. Three professional accountancy associations operate in Albania. ICA (The Institute of Certified Accountants), AAFEA (The Association of the Accountants and Finance Experts of Albania, ACA (Association of Certified Accountants (Shkurti, Leka, Bahiti, \& Manoku, 2011),

As well as almost 1200 registered accountants. They have the title Certified Accountants and practice their profession in various ways. The new law of accounting states that the only responsible institution is the National Standard Accounting (NAS), the National Accounting Council (NAC). This institution operates according to the international standards on accounting IAS/IFRS. They started to effectively report from January 2008, after two years, which were needed to implement this process. Still there is a lot of progress that needs to be done. After implementing the NAS, analysis reveals the problems and difficulties in applying this process. One of the problems was the low level of standard knowledge of the employers who prepared the financial statements. Secondly, it may be possible that the law "For Accounting and Financial Statements" is not directly enforcing the penalties that should be initiated when the standards are not applied correctly (Hoxha and Bollano, 2009; Shkurti and Leka, 2010).

Üç and Haxhiraj, (2015) investigated internal audit quality and perception of IIA standards by internal auditors working in the banks in Albania. They conducted a questionnaire to collect data and analyzed with ANOVA and t-tests. The findings of the research show that internal auditors in banking industry comply with the principles in the IIA standards to provide a certain size of quality in internal audit. ANOVA did not show significant differences between demographic groups of the participant such as education level and experience.

\subsection{Authorized Auditors Profession}

In Albania the process for the auditing profession started in 1995, by the issuing of the 2 regulations by the Government of Albania. These two regulations were approved on 2 October 1995. The Institute of Authorized Chartered Auditors (IEKA) had the main role of improving and developing this profession by making the improvements ethical and professional, and the procedures of quality control standards ethical etc. According to the laws "On state owned-enterprises" and "On commercial companies" there is demand for statutory audit to be performed by professional audits that are authorized and independent. IEKA guarantees trainings and professionalism by supervising the work and by being supervised by the Minister of Finance.

The profession of Chartered Auditors is supported by two main projects, financed by the EU, named the PHARE programs.

These two projects were implemented in different periods between the years 1996-2000 and their objectives were to create and consolidate the IEKA institute and to test the auditors that wanted to be Authorized Chartered Auditors. This part of the project was followed by ATC, a British Training Firm of London. In the following years, 1998- 2000 they had the technical support led by the French institute of Accountants and Auditors (Cela, 2004).

\section{Research Methodology}

A questionnaire was prepared to explore the attitudes of internal auditors towards their practice and their work; the questionnaire was based on the general literature and experience of the authors. The answers to the following questions were substantially researched in the questionnaire. Various questions were asked in the process such as, does the statutory law support them or not? Another question that was raised was whether these regulations, which were adopted from developed countries, need to be adapted better to be appropriate for a country like Albania. Are they free from bias and do they provide independence to the internal auditors at work? There are also other considerations in the questionnaire, for example, the degree of professionalism of Albanian internal auditors. The questionnaire consists of two parts. The first part collects information about the respondents' background: qualification, gender, and experience. The second part covers the respondents' attitudes towards the statements. A five-Likert scale has been used to measure the attitudes of respondents regarding the statements presented in the questionnaire, which were allocated as follows; (5) for the situation strongly agree, (4) for agree, (3) for the situation is neutral, it specified with 'neither agree nor disagree' (2) for disagree, and (1) for 'strongly disagree'.

\subsection{Data Collection and Sampling}

The population of the research is made up of all actively working internal auditors in Albania, both in the public, private sectors. In Albania, it is not required to register to an association or body to perform internal audit, thus solid information about the number of total internal auditors in Albania could not be found. Therefore, we tried to reach different internal auditors who operate in public and private sectors, both males and females, in the limits of time and costs letting us. 200 questionnaires were distributed and 169 of them collected back as fully completed. Therefore the 
sample of the study is 169 which 88 of them are male and 81 respondents are female. The other demographics of the research can be found in the table below.

Table 1. Demographics

\begin{tabular}{llllll}
\hline Qualification & Frequency & $\%$ & Experience & Frequency & $\%$ \\
\hline Bachelor degree & 57 & 33.7 & less than 5 years & 70 & 41.4 \\
Master degree & 73 & 43.2 & from 5-10 years & 62 & 36.7 \\
PhD & 39 & 23.1 & more than 10 years & 37 & 21.9 \\
Total & 169 & 100 & Total & 169 & 100 \\
\hline
\end{tabular}

\subsection{Data Analysis and Findings}

The internal reliability of the questionnaire was tested with Cronbach`s alpha test with a result of 0.82 , an acceptable level of internal reliability (Bryman and Bell, 2011). We present and discuss the research findings the following order: independence, degree of professionalism, the use of international internal audit standards, and existing regulations.

Table 2. Descriptive Statistics of Independence

\begin{tabular}{lll}
\hline Statements & Mean & Std. Deviations \\
\hline $\begin{array}{l}\text { 1. Internal audit profession in Albania is } \\
\text { very important. }\end{array}$ & .40 \\
$\begin{array}{l}\text { 2. Public sector internal auditors in Albania } \\
\text { are totally independent. }\end{array}$ & 3.30 & 1.03 \\
$\begin{array}{l}\text { 3. Private sector internal auditors in Albania } \\
\text { are totally Independent. }\end{array}$ & 3.56 & 1.02 \\
\end{tabular}

Before reviewing auditor independence, we wanted to explore the perception of the profession in the country from perspectives of the respondents (internal auditors). In general, we can say that there is a positive attitude towards the profession; a very low standard deviation ensures that there is a consensus among internal auditors; they all seem to have a very positive perception. The independence of internal auditors has always been discussed separately, as a comparison between public and private sector independence. The independence of the public sector internal auditors, as seen by the results has a higher standard deviation, 1.03, which indicates that there is not a consensus in higher levels, compared to the private sector. And the mean is lower than the attitude towards the private sector. Reflecting on this matter, one can see that the perceived corruption of the public administrations and the politicians as the main reason of this deviation. The 3rd result also has a higher standard deviation compared to the overall result. 1.02 It is very close to the result of the second result. These two results demonstrate, the general opinion about the independence in either public or private sector is not high and the opinions appeared dispersed. In a deeper analysis, the weak independence in the public sector can be connected with corruption, but in the private sector the main reason for this result may be the low quality of staff, as a result of recruitments made based on strong recommendations and connections and not merit. According to internal auditors, it was empirically proved that private sector internal auditors are more independent than internal auditors in public sector in Albania. 
Table 3. Descriptive Statistics of degree of professionalism

\begin{tabular}{|c|c|c|}
\hline Statements & Mean & Std. Deviations \\
\hline $\begin{array}{l}\text { 1. Internal auditors in Albania are able to } \\
\text { prevent fraud by performing their job }\end{array}$ & 3.76 & .95 \\
\hline $\begin{array}{l}\text { 2. Internal auditors in Albania are able to } \\
\text { detect fraud by performing their job }\end{array}$ & 4.06 & .83 \\
\hline 3. I am very sticky to the annual audit plan. & 4.21 & .64 \\
\hline $\begin{array}{l}\text { 4. I am very seldom appointed to the tasks } \\
\text { which are not specified to the Audit Plan. }\end{array}$ & 4.02 & .83 \\
\hline $\begin{array}{l}\text { 5. I cannot report my findings without them } \\
\text { being checked by my supervisor. }\end{array}$ & 4.39 & .70 \\
\hline $\begin{array}{l}\text { 6. Internal auditing gives clear evidence of } \\
\text { the extent to which knowledge is being } \\
\text { effectively managed and indicates where } \\
\text { improvements are needed. }\end{array}$ & 4.38 & .66 \\
\hline $\begin{array}{l}\text { 7. The internal audit must evaluate the } \\
\text { adequacy and effectiveness of controls } \\
\text { responding to risks within the organizations } \\
\text { governance, operations, and information } \\
\text { systems. }\end{array}$ & 4.51 & .59 \\
\hline
\end{tabular}

The above results show us a positive attitude towards the profession, even though a higher standard deviation gives us the idea that not all the auditors agree with the degree of professionalism. The auditors may be more professional in detecting mistakes, as seen in the second result, where the standard deviation is lower. As we can see from the third result to the seventh, the attitude of internal auditors was controlled in some cases. The findings, based on the views of internal auditors, imply that internal audit application in Albania has a certain level of quality and professionalism.

Table 4. Descriptive Statistics the use of International Internal Audit Standards

\begin{tabular}{lll}
\hline Statements & Mean & Std. Deviations \\
\hline $\begin{array}{l}\text { 1. I properly use international internal } \\
\text { auditing standards during my work. }\end{array}$ & & .39 \\
$\begin{array}{l}\text { 2. International internal auditing } \\
\text { standards are easily understandable }\end{array}$ & & \\
and helpful for internal auditors in & & \\
Albania. & &
\end{tabular}

Analyzing the adoption and use of international standards, in the results provided in the above table. We find that the use of international standards is wide spread, and the vast majority of the internal auditors confirm that they properly use the standards. Moreover, the second result of the table above, demonstrates that auditors find the international standards understandable and helpful in their work. However, for the second result; the mean is lower in terms of a strong positive attitude, and the standard deviation is high, which shows a lack of consensus among the participant auditors.

Table 5. Descriptive Statistics of existed regulations in Albania

\begin{tabular}{lll}
\hline Statements & Mean & Std. Deviations \\
\hline $\begin{array}{l}\text { 1. I believe that statutory law is sufficient and satisfactory } \\
\text { for internal audit profession in Albania. }\end{array}$ & 3.46 & 1.13 \\
$\begin{array}{l}\text { 2. The statutory law is very applicable by auditors in } \\
\text { Albania. }\end{array}$ & & .97
\end{tabular}

According to the research findings of table V, we can say that changes are needed to the Statutory Law on Auditing in Albania (here after law). The first result about the law, presents a high deviation standard of 1.13, this higher 
standard deviation, compared to all the other results in the questionnaire, indicates that the law may not be explicitly assessed as satisfactory or sufficient. Changes are needed, with the recommendations and needs of internal auditors in Albania. As we conducted questionnaire we found out that, auditors think that the existing law is good, but not adapted sufficiently as it is taken from developed countries, and in some cases the law cannot match the peculiar situations of a developing country like Albania.

\section{Conclusion}

In this paper we presented the current status of internal auditing in a post-communist country, under the case of Albania. We mainly focused on the independence of the internal auditing profession, the degree of professionalism, and the use of international standards and existing regulations. As seen by the results it is clear that internal auditing is an important profession, which needs to be supported and developed. The research findings clarify that internal auditors can be independent in Albania and the private sector provides a roadmap into independence. Internal auditors from different sectors participated; this showed us their potential, as seen by the results, the internal auditors in Albania are quite capable. They are professional and able to detect and prevent fraud in their companies. In this paper, we also examined the international standards of auditing that are used by Albanian auditors. The international standards are really helpful for internal auditors in Albania, although we do see gaps for improvement. The standards need to be adjusted and explained better so they are understood and applied easily in Albania. We revealed some of the challenges that auditors have dealt with in the twenty years since the transition from communism started. There has been effort by the government to improve this profession to international standards. One of the many challenges faced we saw was, the trend of internationalization in accounting and auditing standards, as part of the broader global adaptation phenomenon, and the costs/benefits associated with this phenomenon for a small country like Albania. According to the research findings, existing regulations were not sufficient to perform the internal auditing profession at a high, accurate level. In adapting the international standards, local circumstances must also be taken into account, especially in countries that are subject to a transition period, like Albania. Numerous recommendations may be given according to concrete steps that can be taken, to help the ongoing development of this profession, into international developed country status. The focus of these recommendations is to create a new method of auditing, where besides the regular internal auditors. Public and private functions can contract, external part time advisors, who can evaluate not only the financial department, but also the actual practices followed by employees, and the performance of the staff auditors, human resources department, IT and all other sectors of a company that need to function at a high level, so the company can function at a high level.

\section{References}

Bello.H. (2012). Roli i Auditimittë Brendshëm dhe Zhvillimi Profesionali Auditorëvenë Sektorin Publiknë Shqipëri. Internal Auditing Role and the Professional Evolution of Auditors in the Public Sector in Albania, Forum in Universiteti Europiantë Tiranës.

Bryman, A., \& Bell, E. (2011). Business Research Methods. Oxford: Oxford University Press.

Bideleux, R., \& Jeffries, I. (2007). The Balkans A Post-Communist History. London \& New York: Routledege.

Cela, H. (2004). Towards application of new standards on accounting and auditing-Albania challenge on implementing IAS/IFRSs and ISAs. Tirana: Albanian Institute of Authorized Chartered Auditors.

Hoxha. E, Bollano.J. (2009). Accounting Standards in Albania Challenges of first time application of AS in Albania. International conference "Economic Policy and EU integration".

Jefriies, I. (1993). Socialist Economies And The Transition to the Market a guide. London \& New York : Routledge. https://doi.org/10.4324/9780203218525

Lavigne, M. (1999). The Economics of Transition From Socilaist Economy to Market Economy. New York: Palgrave.

Law 7638. (1992). On Commercial Companies, articles pp. 167-185.

Shkurti, R., \& Leka, B. (2010). Development of the Accounting Profession in Albania in the New Era of Market Economy. Studies in Business and Economics, 5(3), 247-258.

Shkurti, R., Leka, B., Bahiti, R., \& Manoku, E. (2011). Changes in Financial and Accounting Environment in Albania and The Impact on Practitioners. Annales Universitatis Apulensis Series Oeconomica, 13(1), 57-65.

Üç, M., Haxhiraj, E. (2015). Perceptions on IIA's Standards and Internal Audit Quality: Evidence From Albania Banking Industry. Mediterranean Journal of Social Sciences, 6(1), (5), 147-155. https://doi.org/10.5901/mjss.2015.v6n1p147 